\title{
人工第一胃におけるガス産生像とその飼料価値評価への 応用に関する研究
}

I. ガス産生像の基質による特異性

小原正哉・杉橋孝夫

（日清製粉株式会社中央研究所）

(1972. 4. 1 受付)

給与飼料の差暴によって, 第 1 胃内に産生されるガス が量的にも，質的にも变化するととについてはよく知ら れている6 $6,7,10,11,15,16,20)$ 。乙の種のガスは, 発生源的には

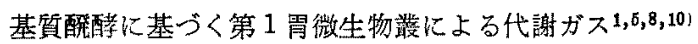
と，産生された揮発性脂肪酸類 (VFAs) と第 1 胃液内の 重炭酸塩との緩徱作用に上って生ずる $\mathrm{CO}_{2}$ ガズ とが主体をなしていると考えられる。とく後者の発生 機構についてはVFAsの産生が供与飼料の可消化エホル ギーのほほ $80 \%$ におよぶとされる点からみて2,4,18,211， その第 1 胃内のガス発生に占める役割はかなり高いもの と思われる. 扇元ら ${ }^{19}$ は柴田ら201の酸醉管法により山羊 の第 1 胃採取液のガス産生能がその所定時間での VFAs 産生之高い相関関倸にあることを見出している。

一般に in vitro 条件下でのガス原生像については第 1 胃微生物丵の活性を知る手法として，とくにリン酸綑

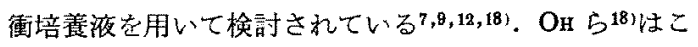
のリン酸緩画系に沶いて同一基質の場合に VFAs 産生 值と産生がス值との間相関関係があるとしている。乙 かし，条野と神立ら12/炕よれ゙，この関係は異なる基質 の場合には見られないが，ガス産生総量が基質によって 異なることを明らかにし，微生物菝の代謝ガス産生も基 質によって異なることを示している。

以上の諸知見によ机ば第 1 罥内のガス産生像はその基 質としての飼料の諸性質, こくに符 1 胃微生物萑の活性 に関連する成分，あるいはVFAs 鷹生に関与する質の 差異, それらの量あるいはバランスなどを全体として反 映しているように思われる。すなわち，産生ガス全体が その基質としての飼料の栄䓹洒值をあらわしている可能 性があり，とくに人工第 1 胃整酔ガスの産生像はなえら かの形で飼料価值判定法として応用できるのではないか と考えられる.乙かしながらとくにこの種の観点からの ガス産生像に関して検討した報告はみあたらない。

筆者ら活人工第 1 胃に和けるガス産生学培養全時間で
の総量としてではなくとくにその時間中でのガス産生 速度の変化像としてみた場合について，以上の観点分ら の一連の検討を行なったところ，その飼料価值評洒への 応用性に関するややまとまった知見をうることができ た.そこで，今回はまずその実験方法について，とくに 測定ガス值の醴醉槽間での定常性, および実験間での再 現性ならびにこの種の検討において要求されるガ大産 生像の基質による特異性について検討した結果報告す ろ.

\section{実 験 方 法}

1) 第 1 胃微生物對之供試培養液: 粗飼料主体 飼料 （市販乳牛用配合飼料 $1.2 \mathrm{~kg} /$ 日/頭，1亦科主体混合良 質牧乾草の自由採食)で飼意した第 1 胃フィストラ装着 牛より第1胃内容物をよく混合して採取し，その重量 (g) 3 に対して, 容量 $(\mathrm{m} l)$ で 2 の割合になるように人工 唾液を混合，これを4 重ガーゼでろ過搾汁し，その售汁 液を第 1 胃微生物蔆液とした。供試人工唾液は MCDouGALL ${ }^{17)}$ の重炭酸塩䌅㣫塩溶液を用いた。第 1 胃微生物 叢液を $39.5^{\circ} \mathrm{C}$ に保温し， $\mathrm{CO}_{2}$ ガス老 10 分間通して $\mathrm{pH}$

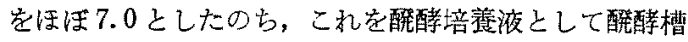
に分注した。

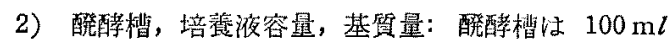
容三角フラスコを用い，Fig. 1 に示したように注射器の 先端が結合できるビニール渞管を，槽内から導いたがラ ス細管に接合したゴム栓からなる。ビニール導管には開 閉用にスクリニーコックを付した。培養液量はガス測定 上の便宜を考慮して検討した結果に基づて，供試基質 量 $1.5 \mathrm{~g}$ に対して $50 \mathrm{ml}$ 它加总るのを原則とした。供 試基質はとくに粉末のむのでない限り， $3 \mathrm{~mm}$ 径ロスク リーン它付したウイレー式粉砕機により汾砕したものを 用いたが，とくにスクリーンに残存したものを別にする ことなく全体家回收してよく混合して使用に供した。精

日蓄会報，43，(10)：567-573。

1972. 10. 


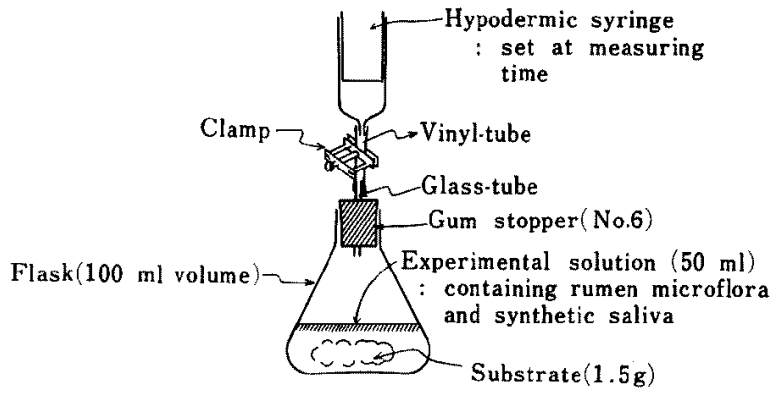

Fig. 1. An artificial rumen fermentor for measuring the gas produced per unit time by the experimentalmicrobes solution-substrate phase

蜜のような流動態のものはそのままを用いた。これらの 基質と培蒦液はできるだけ手早くよく均一に混合し，両 者の接触が均一になるようにした。

3）培養開始と測定ガス蓄積開始特点 :上述の培養液

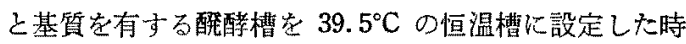
点を培䬭開始時点とした。その後ほぼ 1 時間でその産生 ガスは in vivo に括ける第 1 胃内容物様の臭気学带び, この時間域からほほ定常的ながス産生がみられるので， 本検討における測定ガスの蓄積開始時点を培養開始後 60 分とし，その後の産生がス量測定に借えた。

4）産生ガスの測定方法：産生ガスの測定は酸酲槽の 導管に $10 \mathrm{~m} l$ 目盛, 支るいは $50 \mathrm{~m} l$ 目盛注射器のいす れかを結合し，そのスクリューニックを開いたときに噴 出してくる所定の単位時間内に蓄積したがス定採取亦る 方法によった。すなわち，噴出ガ大で内筒が上昇，つい で停止した時点でコックを閉じ，その探取がス容量を目 盛で読取った，測定の後，てのガスは葉却するととも に，注射器はつぎの醗酵瞥のガス測定にあて，同一実験 内では同一の注射器を用いた。

供試測定時間の間隔哇実歌により 20 分間隔市るいは 1 時間間隔としたが，20 分間隔測定では $10 \mathrm{~m} l$ 目盛， 1 時間間隔では $50 \mathrm{~m} l$ 目盛の注射器を用いた。あらかじ あ検討したところ両注射器によるガス測定值の遠いの程 度は大きくはなかった。なお，注射筒壁の潤滑は水のみ で行なった。

0 点調整：以上の一定時間間隔ごとのガス測定時点で

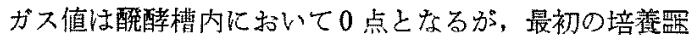
始後 60 分の留積開始㭙点においても同椂にガス0 值を 求るた。すなるら，すべての実駼においてその実験に用 いる注射器により培䔃開始後 40 分時点で所定の操作を 行なってガス定採取し，乙れを予備操作としてさらにそ の後 20 分特点(ガス蓄穑開始時点)で同㥞にガス探取を
行ない0点を調整し，その後のガス測定に備え $7=$

5) ガス産生速度おさびガス産生曲線：各測定 時点で測定されたガス量は測定時点の時間間隔に より $\mathrm{m} l / 20 \mathrm{~min}$ ，あるいは $\mathrm{m} l / \mathrm{hr}$ であらわし， これをガス産生速度と呼ぶことにした。また，䋡 軸をがス産生速度，横軸を時間としたがス産生速 度の経時的変化曲線をガス歷生曲線と呼称した。

\section{結果および考察}

1) ガス産生速度の発醉槽間における変動

供試注射器法におけるガス測定值の醇酵槽間変 動定知るため，供試基質を異にした場合（実験 I）， 基質は同じどあるが供試人工唾液量を異にした埸合（実 験II）について，それぞれ多数の醗醅槽学供した所定の

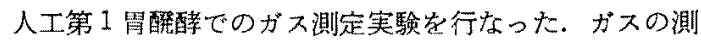
定は $50 \mathrm{~m} l$ 目盛注射器を用いて 1 時間間隔に行ない, $\mathrm{m} l / \mathrm{hr}$ 単位のガス産生速度を求めた。广お，ガス測定

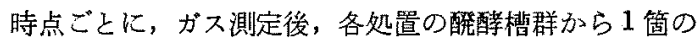
酲醉槽を $\mathrm{pH}$ の測定のため摭きとった。各実験でえられ た笑測值について処置の違い，测定時点ごとに平均值と 変動係数を求わた. 結果は Table 1 のと打りである.

実験 IとIをとおして，ガス産生速度の变動係数注高 いもので, $5.9 \%$ ，低いもので $0.8 \%$ であった：これら

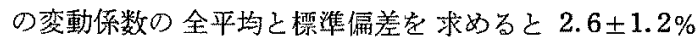
で若干のばらつきはみられるが，基質の種類，培養液条

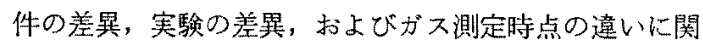
係なく酸酵槽の違いによるガス産生速度の測定值の変動 の小さいことが認められる。

実駼 $\mathrm{I}$ でえられたガス座生速度の基質間差検定した ところ、いずれの測定時点においてもその平均值間の差

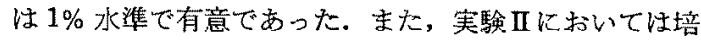
金液条件が異なると同一基質に执いても測定時点によっ ては有意にガス産生速度が異なることを認めだ、これら の結果は本供試实験方法およびそのガス産生速度の概愈 が基質の変化要因，あるいは培意液の違いを形成する要 因などの各種要因の検討に応用できることを示したこと になるう。

なお，各測定時点で拔きとった醗醉槽におけける $\mathrm{pH}$ 測定した結果，開始時 pH 6.9 のものが 10 時間の培鏴 時閒内に処理 No. 1，2および4に就い6.2の附近に 変化したにすぎず，とくに異常な变化を認めなかった。 しかし，No. 3 においては pH 5.5 に字で降するのを 認めた。この結果からある種の基質に打いては供試人工 憔液の増量の必要性のある場合があるもの之思われた。 
ガス産生像の基質による特學性

Table 1. Variation of gas-production rates obtained from different experimental fermentors

\begin{tabular}{|c|c|c|c|c|}
\hline & \multicolumn{4}{|c|}{ Gas-production rate $(\mathrm{m} l / \mathrm{hr})$} \\
\hline Incub. time (hr) & 2 & 3 & 4 & 5 \\
\hline \multirow[t]{3}{*}{$\begin{array}{l}\text { Experiment } \\
\text { No. }\end{array}$} & $\mathrm{n}($ mean \pm S.D.)C.V. & $\mathrm{n}(\operatorname{mean} \pm$ S.D. $)$ C.V. & n(mean \pm S.D. $)$ C.V. & $\mathrm{n}($ mean \pm S.D. $)$ S.D. \\
\hline & $11(10.2 \pm 0.30) 2.9$ & $10(10.5 \pm 0.28) 2.7$ & $9(10.0 \pm 0.1) 1.0$ & $8(11.3 \pm 0.38) 3.4$ \\
\hline & $10(7.4 \pm 0.44) 5.9$ & $9(8.5 \pm 0.37) 4.4$ & $8(7.9 \pm 0.09) 1.2$ & $7(8.7 \pm 0.22) 2.5$ \\
\hline \multirow{2}{*}{ II $\left\{\begin{array}{l}3 \\
4\end{array}\right.$} & $9(15.7 \pm 0.31) 2.0$ & $8(16.1 \pm 0.13) 0.8$ & $7(19.1 \pm 0.17) 0.9$ & $6(23.3 \pm 0.35) 1.5$ \\
\hline & $9(12.7 \pm 0.39) 3.1$ & $8(13.0 \pm 0.48) 3.7$ & $7(14.7 \pm 0.29) 2.0$ & $6(18.6 \pm 0.35) 1.9$ \\
\hline Incub. time (hr) & 6 & 7 & 8 & 9 \\
\hline \multirow{2}{*}{$\mathrm{I}\left\{\begin{array}{l}1 \\
2\end{array}\right.$} & $7(13.7 \pm 0.34) 2.5$ & $6(13.6 \pm 0.34) 2.5$ & $5(12.0 \pm 0.14) 1.2$ & $4(9.9 \pm 0.12) 1.2$ \\
\hline & $6(9.9 \pm 0.38) 3.8$ & $5(10.9 \pm 0.20) 1.8$ & $4(11.5 \pm 0.46) 4.0$ & $3(12.2 \pm 0.29) 2.4$ \\
\hline \multirow{2}{*}{ II $\left\{\begin{array}{l}3 \\
4\end{array}\right.$} & $5(27.9 \pm 0.50) 1.8$ & $4(29.5 \pm 0.86) 2.9$ & $3(24.8 \pm 0.30) 1.2$ & $2(18.8 \pm 0.36) 1.9$ \\
\hline & $5(25.3 \pm 0.71) 2.8$ & $4(34.1 \pm 1.23) 3.6$ & $3(35.1 \pm 1.26) 3.6$ & $2(31.0 \pm 1.12) 3.6$ \\
\hline
\end{tabular}

n: No. of experimental fermentors, S.D.: Standard deviation, C.V.: Coefficient of variation (\%)

* Substrate No. used in each experiment I or II

No. 1: corn, No. 2: corn+biuret $(200 \mathrm{mg} / \mathrm{g}$ of $\operatorname{corn})$, No. 3: wheat feed flour, No. 4: wheat feed flour $+\mathrm{more} 30 \mathrm{~m} l$ synthetic saliva

以上の実験においでは醗醉槽の最小供試数が 1 処理 2 槽の場合の变動它みたが，そのガス值の変動俰数は処理

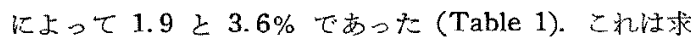
めた全係数の変動の範国に入る值で, 異常值ではない: したがって供試醗酵榑数としては 1 処理に最小 2 槽でも 処理間の差異文ることが可能であると考えられる。

2）ガス産生速度の基質による特異性

以上の実験において基質間にがス産生速度の差異が办 られたが，この基貿開差の再現性它若千の基質について 検討するための実験老行なったすなわも，第 1 胃微生 物採取用のフィストラ装着牛は一貫して同一の飼料で飼

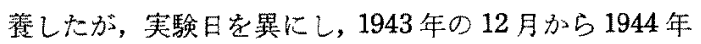
の2月までの冬期間，拉よび同年3月か力5 月までの春 期を通じて，任意の日に所定の人工第 1 胃ガス測定実験 を繰返した．醇酵槽数は供試基質 $(3.0 \mathrm{~g} / 50 \mathrm{~m} l$ 培養液) 1 種あて 2 槽とし，とくに培養時間は 3 時間とし培養開 始後 1 時間より 3 時間までの 2 時間に交ける 20 分間隔 でのガス測定を行ない，その2 榑 12 测定值の平均がス 産生速度 $(\mathrm{ml} / 20 \mathrm{~min})$ を各供試基質について求わた。

結果は Table 2 のとおりである.

Table 2 によ机ば供試基質の平均ガス夝生速度の变椇 は冬季あるいは春季のいずれの実験日に和いてもとくに 大きくはなかったことがかかる。季節間には大豆粕に拀 いて冬季 $13.2 \mathrm{ml} / 20 \mathrm{~min}$, 春季 $15.0 \mathrm{ml} / 20 \mathrm{~min}$ とそ の值に若干の差を光たが，供試基質のいずれるての季䬣 平均值間の差は有意ではながった，基質間のガス産生速 度の順位忙大豆粕〉アルファルフォ(D)>稻的らであっ
Table 2. Variation of average gas-production in different experiments

(Incubation: $3 \mathrm{hrs}$ )

\begin{tabular}{|c|c|c|}
\hline Substr & $\begin{array}{c}\text { No. of } \\
\text { experiment }\end{array}$ & $\begin{array}{c}\text { Gas-production rate } \\
-(\mathrm{m} l / 20 \mathrm{~min})- \\
\text { mean } \pm \mathrm{S} . \mathrm{D} .\end{array}$ \\
\hline
\end{tabular}

- Winter season-

\begin{tabular}{|c|c|c|c|}
\hline Soybean $m$. & 8 & $13.2 \pm 1.1$ & 8.5 \\
\hline $\operatorname{Alfalfa}(\mathrm{D})$ & 6 & $10.0 \pm 0.8$ & 8.1 \\
\hline Rice straw & 8 & $4.1 \pm 0.4$ & 9.7 \\
\hline Blank & 8 & $1.1 \pm 0.2$ & 22.7 \\
\hline \multicolumn{4}{|c|}{-Spring season- } \\
\hline Soybean m. & 7 & $15.0 \pm 1.0$ & 6.8 \\
\hline Alfalfa(D) & 7 & $10.7 \pm 0.8$ & 7.5 \\
\hline Rice straw & 7 & $4.1 \pm 0.2$ & 5.7 \\
\hline Blank & 7 & $1.1 \pm 0.2$ & 20.3 \\
\hline
\end{tabular}

* Sample $3.0 \mathrm{~g}$ in $50 \mathrm{~m} l$ incubation solution

たが，この順位は冬季 8 実験，春李 7 実験のいずれの实 䮦においても変らなかった。

以上の結果办ら，少なくと同一の飼養条件の牛の第 1 䁌微生物菨を用いた場合，所定の実験条件で測定され るガス産生速度の実験間での再現性は非常に高いもので あることが認められる。これはガス産生速度の基質によ る特異性を明らかにするるのであらう。

3) 各程飼料原料のガス産生速度の経時的変化 ガス産生速度には基質特珙性があると考方られるが， 基質の経時的な䣫醉变化を考无ると，その速度の経時的 变化をあらわしたガ不産生岶線も特異的であることが予 


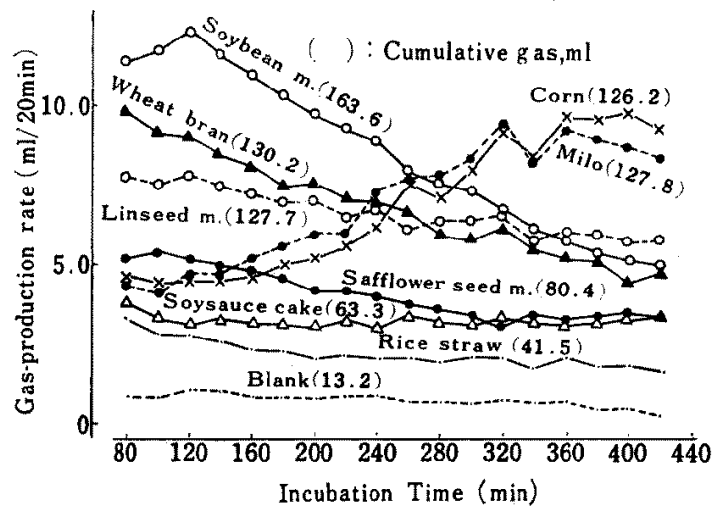

Fig. 2. Gas-production curves of various feedstuffs (I)

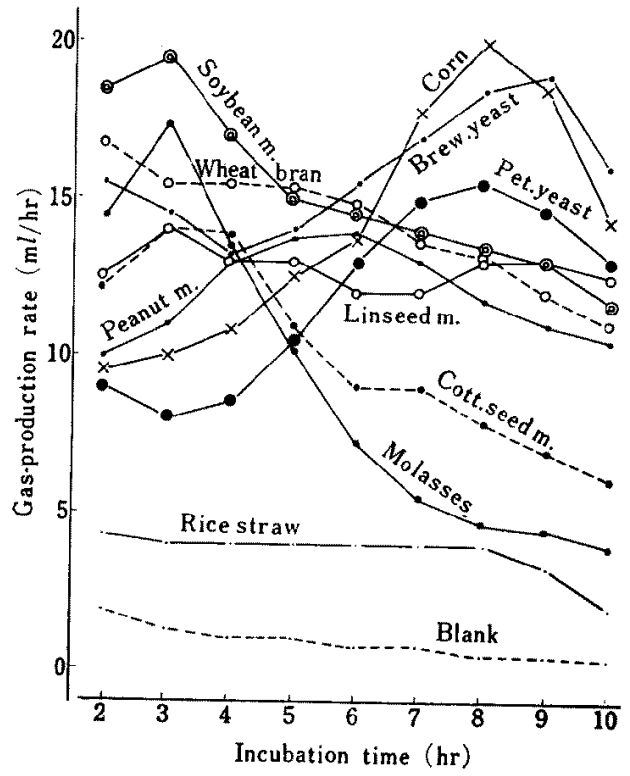

Fig. 3. Gas-production curves of various feedstuffs (II)

想される.この点艺さらに各種の配合飼料原料定基質と して㮩討した.

まず， 8 種類の飼料荧筫として，各基質ごとに 2 酸 酵槽老供し，所定の $10 \mathrm{~m} l$ 目盛注射器に上る 20 分間阸

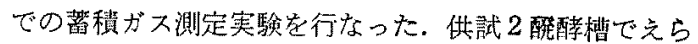
れた各ガス産生速度 $(\mathrm{m} l / 20 \mathrm{~min})$ の平均值についてガス 産生曲線を作成すると Fig. 2 のごとくであった. Fig. 3 には 9 種類の飼料について $50 \mathrm{~m} l$ 目盛注射器で 60 分ご とに測定した同様の実験結果をガス産生曲線として示し た.
供試基質のうら，大豆粕は 20 分ごとの測定 (Fig. 2) では培養開始 120 分後の時点で最高のガス産生速度を示 し，以後恃連続的にこれが低下したが，60 分ごとの測定 (Fig. 3) でも同一の傾向方認められた。

培蕉初期に最高力゙ス産生速度を示与曲線はフスマ, 綿 实粕，糖蜜の場合にも認められた (Fig. 3). あまに粕と サフラワー粕は 20 分ごとの測定では経時的にゆるやか にやや低下する傾向の曲線安示したが，市まに粕につい ては 60 分ごとの測定ではこれを確認できなかった。こ

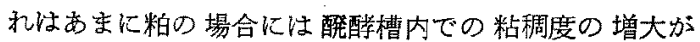
あり，産生されたガスの確かな測定が困難になったこと によるものではないかと思われる，乙ょら油粕のガス産 生速度は全測定時点索通して稲わらよりやや高い程度の 低い值を示したにすぎなかった。しかも，両者の曲線像 はよく類似していた。

以上の諸基質の場合は，そのガス産生曲線はいずれも 基質特異的に固有の程度のガス産生速度を保持し，培養 ほほ 3 時間までのガス産生速度によって曲線の特幑が明 らかにされているととがわかる。

しかしながらとうもろこしにおいては最高ガス産生 速度が培養 3 時間以後代認めら机，乙の傾向は 20 分ご とおよび 60 分ごとの両測定結果 (Fig. 2, Fig. 3) 飞打 いて变らなかったこの種の像の曲線はマイロ，醭母類 (Fig. 3)でも元られた. また，これらとは曲線像をやや 異にしたが，落花生粕に括いても培養 3 時間以内にガス 産生速度の最高値はえられなかった。

いずれにしても，供試した各基質のガス産生曲線は培 養ほほ 3 時間時点までに測定したガス産生速度の平均値 を中心に增大するるのと，減少するもの，あるいは大き な增城を示さないむのとうのあること宗している。す なわち，各基質は培養ほぼ 3 時間時点までにその固有の 程度に異なるガス産生速度を示して，その時間域でのガ 不産生測度の基質による特異性を明らかにするが，さら にそれ以後の培善時間にわたるがス産生曲線が各基質の 違いをより明確にするすのと思われる。本両実驗におい てはとうむるこしの最高がス産生速度が確認された時点 で笑験を中止したが，各基質の違いのガス曲線における 出現状沉からみて，ほほ 10 時間にいたる培養時間でえ られるガス産生曲線が基質の特異性を示しらるようであ

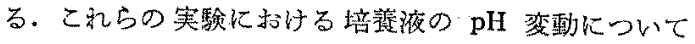
は，培恤開始時の 7.0 に対して，10 時間の実駼終了時 には両実験のいずれの基質の酲酵槽においても $6.2 \sim$ 6.4 の範囲にあり，とくに巽常な $\mathrm{pH}$ 变化㹥認められな かった.

なお，以上えられたガス産生曲線牥各基質に特異なガ 
ス産生速度の程度に応じて，各測定時点における前後の 測定值に関して，連続性のある比較的スムーズな増大あ るいは減少の像を示したが，これ性基質の酲酵变質が各 ガス測定時点に対応して順次に進行していることによる あのと思われる。

\section{4）累積ガス值について}

Fig. 2 の各基質のガス産生曲線上に附記した累積值を みると，大豆粕のそれはとうもるこしよりも大であるこ とがかかる、しかし，らすまと綿実粕の類では 130.2 $\mathrm{m} l, 127.7 \mathrm{~m} l$ 范し，とうるろこしとマイ口の類でそ れぞれ $126.2 \mathrm{ml}, 127.8 \mathrm{ml}$ であった.これらの鱼積ガ 值は 4 基質とも柏互にとくに大きく異なるるのではな かったが，しかし，前者の類と後者の類の曲線像は明ら かに異なるものであった。

これら4基質それぞれ，その成分含量に大きな差のあ ることはよく知られているが，以上の累積がス值の結果

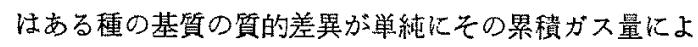
って明らかにされない場合のあることを示している。

ガス産生曲線の前記の諸像からみて，累樍がス值注同 じであるが，曲線像が経時的に対称型它示寸基質が存在 するであるうことは一定の培掋時間䇥設定して考察すれ ば理論的にも理解できるとこるである。したがって，累 積ガス値によって飼料の資の差を推定しようとする試み にはなお問題のあることがあかる。

5）基缷の混合によるガス産生曲線の変動

以上，ガス産生曲線はガス産生速度の基質による特異 性にもとついて基質によって巽なる像宗すものと考方 られたが，乙れが基犋の成分的差異によるものかどうか

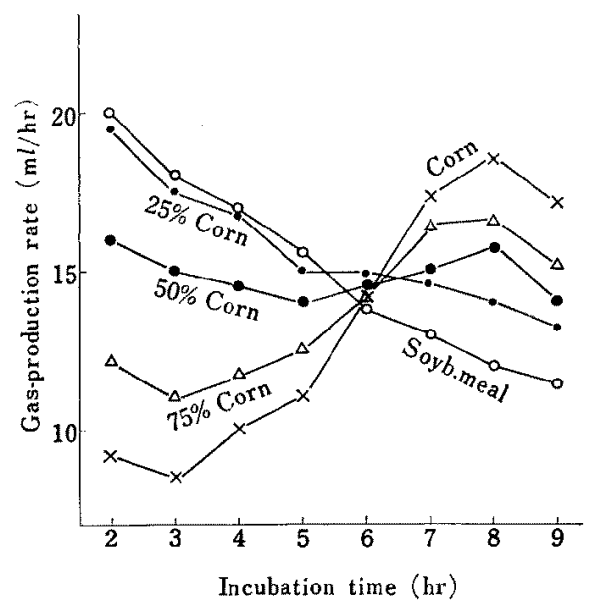

Fig. 4. Gas-production curves of corn-soybean meal mixtures
を明らかにする一端として本检討学行なった。すなる 亏，成分的に異なることが明らか儿知られて招り，以上 の実験によるガス産生曲線が対称的な像を示したとうも るこしと大豆粕についてその混合割合を異にしたすのを 基質己して，所定の醇醉ガス测定実鈋を行なった. Fig. 4 には本実験に供した混合基質をとうもろこしの配合\% で区別してえられたそれぞれのガス鷹生曲線を示した。

Fig. 4 によれば供試徨合基罂の各ガス産生曲線はと5 むるこしと大豆粕の混合比が (25:75)，(50：50) および (75:25) ととうもるこしの割合が高くなるにしたがい とうもるこし旄独のガス曲線に近い像を示し，大豆粕に ついてむ同様のことを指摘できることが認められる。

これらの曲線の変化はさらに繰返し行なった同様の 3 回の実娩においても確認したが，てれらを一括して検討 するため, 各実験でとうもるこしが最高のガス産生速度 を示した培養 8 および9時間時点での 1 実駼各基質 2 槽 の 4 実測ガス值の平均 $(\mathrm{X} \mathrm{m} l / \mathrm{hr})$ の実験間変動と，基 質のとうるるこしの割合 $(\mathrm{Y} \%)$ その変化との間の相関関 係空求めたところ，Table 3 をえた。すなわち，両者間 には明らかに有意に高い相関関係のるることが認められ ₹.

他方, 培善 2 時間と 3 時閒各時点でのガス値の平均之 とうもらこしの配合割合との関係范同様に求めたが，そ の結果は負の回㷌係数を認め，4実験艺とおしてその平

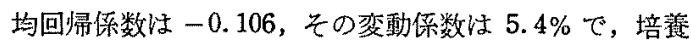
後期の場合 (Table 3) と同梯に $0.1 \%$ 水準で有意な相 關閣係资充た。

これらの結果は，ます供試実験方法によるガス産生曲 線の実跧間における再現性が非常に高く，実験方法の信 頼性が充分にあることを示している。 \&た，本供試基質 においては培徨後期のがス産生速度の加速がとうもるこ 乙特有の成分依存しており，前期のそれが大豆粕特有

Table 3. Correlation between corn percentage in substrate (corn and soybean meal mixture) and average of gas-production rates measured at 8 th and 9 th hour of incubation time

\begin{tabular}{cccc}
\hline Expetl. No. & Regerssion equation* & $\mathrm{r}$ & $\mathrm{p}$ \\
\hline 1 & $\mathrm{Y}=0.064 \mathrm{X}+10.8$ & 0.985 & .001 \\
2 & $\mathrm{Y}=0.084 \mathrm{X}+11.7$ & 0.999 & .001 \\
3 & $\mathrm{Y}=0.057 \mathrm{X}+11.9$ & 0.989 & .001 \\
4 & $\mathrm{Y}=0.086 \mathrm{X}+13.8$ & 0.966 & .001 \\
\hline
\end{tabular}

* Y: Average value $(\mathrm{m} / \mathrm{hr})$ of gas-production rates measured at 8th and 9th $\mathrm{hr}$ of incubation time. $\mathrm{X}$ : Corn percentage in substrate (soybean meal and corn mixture) 
の成分によることを明らがしている。したがって，ガ 不座生曲線忙基質の違いによって変化するが，その变化 は基質の成分と量の差異によることが考えられる。しか し，これがどの椂な成分によるものか，その成分の内容 および量との関係についてはなお検討を必要としよう。

以上, 酸醅ガス産生速度㧍よびその経時的变化像が基 質により特巽的であり，供試実験条件下での艺れらの定 常性を明らかにしえたが，これらは人工第 1 胃でのがス 産生像がなえらかの形で基質の栄荃価值の評伍法に応用 できる可能性堂示唆しているものと若えられる.

\section{要 約}

人工第 1 胃醇䤃槽内に産生されるガス産生像につい て，その飼料価值評伍法への応用の可能性を知るだ， ガス産生速度拉よびその経時的変化(ガス産生曲線)の面 からの一連の検即を意図し，とくに重炭酸塩緩衝の人工 唾液を用いた采でのガス産生像を基質に上る特異性と， 実験方法上してのその定常性の観点方ら検討を加えた。

1）同一実験内での同一基質学供した醗酵槽間のガス 産生速度の变動係数は, 供詮の実験条件下においてガス 測定時点，基質，西るい洪試第 1 胃液の差異に関係な く非常に小さかった．佚試酸醭槽の処理間差は 1 処理 2 醴醏槽の供試でも十分検討できるものと考えられた。

2）第 1 孯微生物對の採取日を異にした実験におい $て$ ，培篒 1 時間後より 2 時間にわたって $10 \mathrm{~m} l$ 目盛注射 器による20 分間隔で測定した供試基質のガス産生速度 の平均值 $(\mathrm{m} l / 20 \mathrm{~min})$ は各基質化固有な程度に異なった が，その固有性江実験日西るいは季節の違いにより影響 されず，ガス産生速度の基質炕よる特異性が明らか心さ れた。

3）各種配合飼料原料のガス産生曲線注 20 分間隔打 よび 60 分間隔のいずれの測定によってもそれぞれ基質 特異的なガス産生速度に応じて異なった，連続的に増減 するスムーズな変化像定示し，关の曲楾像の基質による 特異性が示唆された。また，新積ガス量が同じである基 質においてその曲線像が異なる事実のあること势認如ら れた。

4）成分の堂いがよく知ら机ており，ガス産生曲線が その 10 時間培萑時間内で対称的であったとうもるこし と大豆粕との混合割合の違いと曲線像の变動乙の関係を 検楌したところ，それらの混合彗合に応じて曲線像が有
意に $(\mathrm{P}<0.001)$ 変動卞ること孝認めた。乙れよりガス 産生曲楾の变動为基犋特異的であること崖確認した。

$$
\text { 謝辞 }
$$

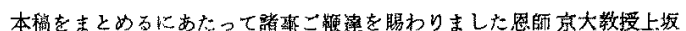

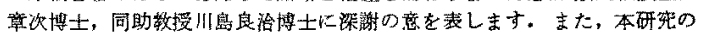

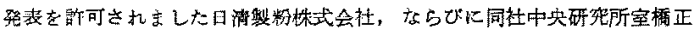

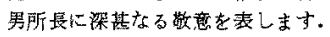

\section{文献}

1) BACHop, T. and S.R. ElsDeN (1960) J. Gen. Microbiol., 23: 457-469.

2) BaLCH, D.A. (1958) Brit. J. Nutr., 12: 18-24.

3) Barnett, A.J.G. and R.L. Reid (1961) Reactions in the Rumen 1st ed. 99, Edward Arnold, London.

4) Carroll, E.L. and R.E. Hungate (1954) Appl. Microbiol., 2: 205-214.

5) eL-Shazly, K. and R.E. Hungate (1965) Appl. Microbiol., 13: 62-69.

6）広瀬可恒・鈴木省三・朝日田康司（1957） 月畜会 報，28：177-180.

7) Hungate, R.E. (1956) J. Agr. Food Chem., 4: 701-703.

8) Hungate, R.E. (1960) Bacteriol. Rev., 24: 353364.

9) Hungate, R.E., R.A. Mah and M. Simesen (1961) Appl. Microbiol., 9: 554-561.

10) Hungate, R. E. (1966) The Rumen and Its Microbes 1st ed. 246-272. Acad. Press. N.Y. and London.

11）神立 誠・松本達郎・風間 雍・菊野恵一郎・D 之瀨幸男 (1955) 農化誌 29: 759-764.

12）条野交雄・神立 誠 (1961) 農化誌, 35: 360-366.

13) Leng, R.A. and G.J. Leonald (1965) Brit. J. Nutr. 19: 469-484.

14) Marcoff, I. (1913) Biochem. Z., 57: 1-70.

15）松本達郎 (1957) 農化誌，31：300-303.

16）松本逯郎・高橋直要 - 今野 勇 (1957) 農化誌, 31: 392-396.

17) McDougall, E.T. (1948) Biochem. J., 43: 99-108.

18) OH, H.K., M.B. JoNEs and W.M. LONGHURST (1968) Appl. Microbiol., 16: 39-44.

19）扇元敬司・柴田章夫・古放登石（1962）日畜会報, 32: $330-333$.

20）柴田章夫・扇元敬司・古坂登石（1961）日音会報， 32: 159-163.

21）柴田章夫（1963） 反贸動物の低級脂肪酸代謝につ いての量的考察, 名古屋大学農学部家畜飼養学教 室業績, No. 3, 安城市, 要知県. 


\title{
Résumé
}

\section{Studies on the mode of gas production in artificial rumen and its application to the evaluation of feedstuffs}

I. Gas production patterns and their specificity by substrate

\author{
Masaya O'HARA and Takao Sugihashi \\ (Central Laboratory of Nisshin Flour Milling Co.)
}

The patterns of gas production in artificial rumen and their specificity by substrate were studied for the development of a simple technique to evaluate feedstuffs, by using a hypodermic syringe technique to determine gas-production rate (GPR).

Substrates were incubated at $39.5^{\circ} \mathrm{C}$ for 3 or $10 \mathrm{hrs}$ of experimental period with a $\mathrm{CO}_{2}$ treatment liquid ( $\mathrm{pH} 7.0$ ) consisted of bovine rumen juice and McDougall's synthetic saliva in the air-tight vessel without bubbling $\mathrm{CO}_{3}$, and the gas production was measured by a syringe at regular time intervals from one hour after the start of incubation.

The results obtained are as follows:

1) Coefficient of variation of $\mathrm{GPR}(\mathrm{ml} / \mathrm{hr})$ obtained from different fermentors with same substrate in an experiment was very small regardless of the difference of incubation time, substrate and rumen juice used.

2) Average $\mathrm{GPR}(\mathrm{ml} / 20 \mathrm{~min})$ of last $2 \mathrm{hrs}$ during $3 \mathrm{hrs}$ experimental time was specific for substrate. This result was invariable for different day or season of the experiment by using rumen juice of cattle fed the same feeds.

3) Timely change of $\mathrm{GPR}(\mathrm{m} l / 20 \mathrm{~min}$ or $\mathrm{ml} / \mathrm{hr})$ during $10 \mathrm{hrs}$ incubation period (gasproduction curve) showed characteristic patterns according to the substrate used. Total of GPRs obtained from a substrate in an experiment not always indicated the substrate specificity.

4) The substrate specificity of gas-production curve was confirmed by the fact that curves obtained by raising the corn (or soybean meal) levels in the mixed substrates of corn and soybean meal approached significantly to the curve of corn (or soybean meal). 